\title{
The significance of faith in the concept of integral knowledge of Vladimir Solovyov*
}

\section{T. Obolevitch}

The Pontifical University of John Paul II in Krakow,

9, Kanonicza ul., Krakow, 31-002, Poland

National Research University "Higher School of Economics",

20, Myasnitskaya ul., Moscow, 101000, Russian Federation

For citation: Obolevitch T. The significance of faith in the concept of integral knowledge of Vladimir Solovyov. Vestnik of Saint Petersburg University. Philosophy and Conflict Studies, 2020, vol. 36, issue 3, pp. 460-472. https://doi.org/10.21638/spbu17.2020.304

The article examines the role and place of faith in the concept of Vladimir Solovyov who is considered to be the creator of the first Russian philosophical system. The purpose of the article is to determine the epistemological and methodological significance of faith in Solovyov's understanding as a special factor of cognition. In order to study this problem, a synthetic method of reconstruction of the thought of Solovyov as well as a method of philosophical analysis was used. First, Solovyov's project of integral knowledge or free theosophy is presented, i.e. synthesis of philosophy, theology, and science. The suppositions of this concept are revealed and its polemical context is indicated, namely, Solovyov's attempt to overcome the abstract or one-sided principles: reason, empirical experience, and faith in order to create an integral system that should unite all types of knowledge. In addition, philosophy as such corresponds to reason, science to experience, and theology to faith. The second part of the article is devoted to the epistemological aspects of faith in the concept of integral knowledge. It lies in the fact that each act of cognition begins with the assertion of the objective existence of its object, which Solovyov describes as faith in a broad sense of the word. Thus, faith has a universal significance as a necessary condition for the cognitive process. The third part of the article discusses the methodological aspect of faith as a key link in the system of integral knowledge. As a result, faith has a dominant role not only in theology, but in all spheres of knowledge, including philosophy and science. Thus, it is possible to conclude that there is no conflict between faith and reason; on the contrary, they complement each other. Solovyov's position is still relevant nowadays.

Keywords: faith, integral knowledge, theosophy, experience, science.

Vladimir Solovyov (1853-1900) is considered to be the first "professional" Russian philosopher and the creator of an original concept of religious thought, described by the terms of all-unity, sophiology and divine humanity (Godmanhood). In his early youth he shared the ideas of materialism and atheism, but under the influence of the holistic concept of Spinoza (who was his "first love in the domain of philosophy" [1, p. 29]), Solovyov returned to Christianity and started working on his own original project of the reconciliation of faith and reason. Indeed, by 1872 "the Orthodox faith regained strength in his soul

* This article was prepared within the framework of the HSE University Basic Research Program and funded by the Russian Academic Excellence Project "5-100", National Research University "Higher school of economics" (Moscow, Russia).

(C) Санкт-Петербургский государственный университет, 2020 
and it is interesting to note that unlike the typical case his abandoned scientism was in a special way combined with his restored religious faith" [2, p. 51]. On December 31, 1872 he wrote to his friend Ekaterina Romanova:

your present error $\langle\ldots\rangle$ is that you are confusing faith in general with one of its forms: with blind, childish, unconscious faith, and that you think there's no other faith. Of course, one doesn't need that much intelligence to refute such a faith - I rejected it when I was thirteen years old. Of course, no person who is to any extent a thinking person can believe in the same manner as when he was a child; and if this is a person with a superficial or limited mind, he does not go further than this easy rejection of his childish faith, fully certain that his nanny's fairy tales or elementary phrases of the catechism represent true religion, true Christianity $\langle\ldots\rangle$. And although God is one and the same, the faith to which more philosophy leads us is not the same as the faith a little mind leads us away from. It is not hard to see that the faith of a conscious, thinking Christian differs in some manner from the faith of an old peasant woman even though the objects of faith are the same in the two cases and both might be true Christians; and the inner sense of faith in the two is the same [3, p. 80].

The Solovyovian goal can be presented as an attempt to rationalize the mysteries of faith. He believed that in order to make the traditional Christian faith attractive to contemporary people, it was necessary to express it in proper philosophical terms and show that there is no conflict between religion and philosophy or religion and science. This reconciliation of theology, philosophy, and science was described by Solovyov as a theory of integral knowledge or "free theosophy". As will be illustrated, faith serves as the first and most important principle for Solovyov at both the epistemological and methodological levels of integral knowledge.

\section{The Context of the Solovyovian Project of Integral Knowledge}

Solovyov, in the spirit of the Platonic and Spinozan traditions, was inclined to emphasize the organic unity of different fragments of reality and its cognition. In particular, he tried to unite the various branches of knowledge that were supposed to be separated from each other. For instance, science, according to the radical positivistic interpretation, ignored any non-empirical (metaphysical and religious) factors. In turn, the most influential speculative philosophical systems of his time, such as Hegelianism, denied both empirical and mystical experience and tried to replace religion with philosophy. Eventually, the traditional Orthodox confession neglected scientific data and philosophical investigations. Solovyov postulated that theology should be expressed in the form of rational reflection as well as maintaining close contact with modern scientific discoveries.

In order to overcome this crisis of science, on the one side, and religion, on the other, he proposed his concept of integral knowledge: the alliance of philosophy, science, and theology in which faith is the element that allows us to know and create the integral vision of reality. In the draft of his unfinished work titled God is all. All becomes God, Solovyov wrote: "All affairs and activity of humanity must bring into harmony or all-inclusive relationship which is expressed in $\langle\ldots\rangle$ the theoretical sphere as free theosophy" [4, p. 21], or integral knowledge. Integral knowledge is also in tune with the Solovyovian ontological concept of all-unity. In his opinion, the ontological link of all beings provides epistemological fullness. In other words, the objective aspect of reality (from the side of its metaphysical nature) treated as an organic organism leads to 
the certitude of its subjective (form the side of knowing subject) perception. Solovyov stressed that all branches of knowledge are of a complementary nature and need each other. Only by taking into account various perspectives - religious, philosophical, and scientific - are we able to discover the inner truth of the universe, both uncreated (God) and created (the world). In this way, Solovyov proposed the internal unity of faith and reason. What is more, it was faith, in the Solovyovian understanding of this notion, which determines the act of cognition. This applies not not only to religion, but also to science and philosophical matters.

In this context, it worth mentioning the essay by Solovyov entitled Faith, Reason and Experience [5]. This is a remarkable example of his polemic with radical empiricism (positivism) and radical idealism (Hegelianism, both of "right" and "left" wings). The article was written in 1877, the same time when Solovyov had been working on his seminal (yet unfinished) book The Philosophical Principles of Integral Knowledge and started writing his doctoral dissertation - Critique of Abstract Principles (published in 1880) as well as delivering his Lectures on Divine Humanity. Hence, the essay Faith, Reason and Experinece reflects early yet extremely mature Solovyovian studies concerning various fields of philosophy (especially ontology, epistemology, philosophy of religion, and philosophy of science). At that time, he sought conceptions that might be an alternative for the defective principles of fideism, pure rationalism, and pure empiricism. This idea is encapsulated by the key words of the title of Solovyov's essay: "faith," "reason," and "experience". The article ends with the announcement of a continuation, which did not appear during Solovyov's lifetime for unknown reasons. The entire text of Faith, Reason and Experience was published in the journal "Voprosy filosofii" ("Issues of Philosophy") in 1994 [6], and then reprinted in the third volume of the Collected Works by V. Solovyov in 2001 .

Most likely, the publication of the Solovyovian article Faith, Reason and Experience in "Grazhdanin" was made possible thanks to Fyodor Dostoevsky (1821-1881), who was the editor of this journal from 1873-1874 [7, p.515] and whom the philosopher cooperated with. Nonetheless, the essay Faith, Reason and Experience did not generate much enthusiasm among the journal's readers. What is more, the well-known and influential publicist and philosopher Nicolas Strakhov (1828-1896), in his letter to Leo Tolstoy (1828-1910) from 24-27.12.1877, felt that the Solovyovian text was unclear: "The small spark of philosophical work is dissolved in a disordered stream of words". Fortunately, the negative criticism did not discourage Tolstoy, who showed a keen interest in the subject and asked his correspondent to send him the text of Solovyov's piece.

The article by Solovyov is an important voice concerning the relationship between faith and knowledge (in the broadest sense of these terms), about which his continuator, Semen Frank, wrote as follows in 1910: "The topic of the relationship between religion and science, knowledge and faith, becomes the most pressing problem of the Western European religious movement - in contrast to the Russian movement, which, due to the underdevelopment of our scientific thinking and our national contempt for exact knowledge, looked down on science from the very beginning" [8, p. 386-387].

Although Solovyov was not the first Russian philosopher who addressed the relationship between faith and knowledge, he was certainly the first to propose a very concrete and original solution to this problem in the shape of a system of integral knowledge. Despite the general "underdevelopment of scientific thinking" mentioned by Frank, in 
nineteenth-century Russia there was a strong and influential group of positivists and materialists who denied any meaning for faith. It was Solovyov who, in discussion with the aforementioned trends, initiated the "Russian movement", as Frank called it - a peculiar model of "revival of religion and understanding of religion" [8, p. 385].

Perhaps Strakhow was right: Solovyov's essay Faith, Reason and Experinece is a bit "talkative". The whole text could be summarized in two sentences:

(1) Faith, reason and experience are "incommensurable proportions," i.e. they belong to different orders of cognition and are irreducible to one another.

(2) Despite their distinctiveness, all three categories need each other.

The direct context (or rather a pretext) of Solovyov's essay was provided by a polemic with the famous book by David Friedrich Strauss (1808-1874), the representative of "leftwing" Hegelianism, entitled The Old Faith and the New: A Confession which amounted to the creed of the German philosopher. Strauss, one of the most determined critics of Christianity, interpreted the person of Christ in his work The Life of Jesus exclusively as a historical person (historischer Jesus), and saw the descriptions of miracles as mythical stories. As John Hedley Brooke reports in his book Science and Religion. Some Historical Perspectives, for Strauss,

It would be far better to acknowledge the historical process whereby reports of the original incidents had been affected by the passing of time, by the accretion of legend, and by human interpretation. $<\ldots>$ Playing off the rationalists against the harmonists, Strauss showed how neither the naturalism of the former nor the supernaturalism of the latter did justice to the gospels as historical documents. $\langle\ldots\rangle$ The science of history had created a watershed. One set of presuppositions took one toward a human, but historically elusive Christ. The other - more traditional allowed the retention of the Christ of faith, but at the cost of severing one's ties with what Strauss called 'our modern world' [9, p. 362-363, 366].

In Solovyov's opinion, Strauss in order to be consistent should have avoided the term "faith" completely, using instead the words "reason" or "knowledge". Meanwhile, the notion "faith" appears in the very title and throughout the entire content of Strauss' book, who describes his position as a "new faith". This means that faith is an irremovable element of the human spirit and his entire existence.

\section{The Epistemological Aspect}

As we have already mentioned, Solovyov developed his own proposal for overcoming the previous, one-sidedness of solutions from the metaphysical, epistemological, and methodological point of view in his works titled Critique of Abstract Principles, The Philosophical Principles of Integral Knowledge and Lectures on Divine Humanity. Specifically, in the onto-gnoseological aspect, Solovyov viewed faith, reason and experience as three stages of every process of cognition. He elaborated the ambitious metaphysical system of all-unity which was supposed to be the "inner", organic unity of all beings. Based on this, he tried to justify the concept of integral knowledge, positing an "external" alliance of philosophy, theology and science. Also, in the article Faith, Reason and Experience discussed here, Solovyov stressed that we first learn about phenomena through external experience, then, reason derives from the detailed, transient empirical data some general concepts, while faith concerns the foundations and principles of 
these empirical facts. In his Lectures on Divine Humanity, the philosopher expressed this thought in the following way:

If material reality, perceived by our external senses, represents in itself only contingent and transitory phenomena, but not autonomous entities or foundations of being, these latter $\langle\ldots\rangle$ must have their own being independent of phenomena. Consequently, to know them as actual we need a special mode of thought activity, which we shall call by a term already known in philosophy: intellectual intuition (intellektuelle Anschauung, Intuition). This activity constitutes the primordial form of true knowledge, a form that is clearly distinguished from sense perception and experience, as well as from rational, or abstract, thinking [10, p.60].

In turn, in his Critique of Abstract Principles, Solovyov wrote: "In any cognition, an object exists for us in a triple way: first, as relatively real in its actual influence on us, that is, in its real phenomenon; second, as relatively ideal in its mental relations to everything; and finally, third, as an absolute object. We experience certain interactions of the object, think of its general characteristics and are sure of its independent, that is, absolute existence" [11, p. 291].

Solovyov tries to explain both the fact of cognition of the constant features of things and the possibility of capturing their changing properties (in Aristotle's language - substance and accidents). In the very process of cognition, he distinguishes three phases. At first, the subject perceives a thing as an independent being. The philosopher calls this stage "faith" or "mystical knowledge": "We believe that the object is". In the second phase, the subject recognizes the idea of the object due to their mutual internal connection of the object and subject in the absolute. Solovyov describes this process by means of the terms "imagination," "intellectual intuition" (Intellectuelle Anschauung), or "intellectual contemplation". As a result, we know "what an object is". Finally, in the last stage described as "mental creation," the idea is expressed in the form of a phenomenon that is currently perceived at the empirical, external level. Thus, "creativity" informs us "how the object manifests itself" [11, p. 303-305]. Solovyov warns us that the above-mentioned order of cognition is only of a "genetical" character, occurring in ordine essendi, while in ordine cognoscendi we first perceive the phenomenon, and only through it can we reach the essence of being. Hence, every object of cognition has three modes: in the phase of "faith" it

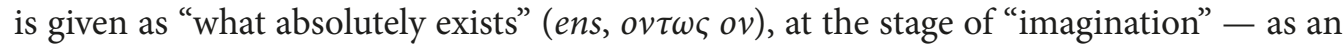
eternal "being" or "idea" (essentia, ovoí ), and in the phase of "creativity" - as a current "phenomenon" (actus, phaenomenon) [11, p. 305]. To begin with, we believe in the real existence of an object of knowledge, then we apprehend its essence and, finally, its manifestation as phenomena, empirical data [12, p. 78].

Konstanty Mochulsky (1892-1948) noticed that Solovyov adopted the three-stage scheme of cognition from his teacher Pamfil Yurkievich (1827-1874). In his opinion, Yurkievich's "religious feeling," "mystical contemplation" and "experience" find their equivalents in Solovyov's "faith", "imagination" and "creativity". Undoubtedly, one could observe a certain similarity between theses two concepts, but, as Mochulsky himself admited, "Solovyov inserts a new content into Yurkievich's scheme" [13, p. 125]. While in Yurkievich's case "religious feeling" had a more practical and ascetic meaning, in tune with the venerable Eastern Christian doctrine of "cardiognosy," the Solovyovian counterpart of this notion - "faith" - is rather of a theoretical character, although also the author of Critique of Abstract Principles was not alien to the idea that the reality is "known to the 
heart" [14, p. 184]. It should be recalled that "faith" as a cognitive category was already present in the teaching of the Slavophiles: Ivan Kireyevsky (1806-1856) and Alexei Khomiakov (1804-1860), who also had a considerable influence on the young Solovyov [15, p. 559-579]. However, while the Slavophiles considered "faith" as an integral moment of intellect as such (labeled by them as "believing reason"), Solovyov sees "faith" as the first stage which precedes learning about "what the object is". In other words, faith is the presupposition and condition of every act of cognition.

Empirical experience and the act of reason refer respectively to phenomena and their metaphysical foundations (essences, resp. ideas) and enable the construction of general, abstract notions, while the act of faith captures the thing itself as an objectively existing, independent being: "faith reveals to us the ruthlessness and substance of the object of cognition" [16, p. 228] by expressing the "non-religious openness of being to the human spirit" [17, p. 118]. In this very sense, faith plays a fundamental role in the entire cognitive process. Faith is not only reserved for the domain of religion but is present in every sphere of human knowledge. "Mystical perception $\langle\ldots\rangle$ can only be explained when we admit that in perceiving ourselves in God, we at the same time perceive all other objects or beings" [18, p. 528]. Faith, therefore, does not contradict reason in any way, but it is the foundation, the initial stage of our perception and understanding of reality. Solovyov describes faith with the help of the folloving metaphor: "The branches of the tree cross and combine in different ways, whereby these these branches and leaves touch one another by their external side. It is symbolizes the external knowledge (i. e., the empirical one. - T. O.). But the same branches and leaves are connected by their common trunk and roots which deliver vital juices to them. This is the mystical knowledge or faith" [11, p. 296].

As we have already mentioned, Solovyovv was fascinated in his youth by the work of Spinoza. It is possible that in his theory of cognition the Russian philosopher consciously refers to his thought, adopting the Spinozian doctrine of three kinds of knowledge: "opinion" or "imagination," due to which "we have notions common to all men, and adequate ideas of the properties of things" [19], "reason" (ratio or cognitio), and "intuition" (scientia intuitiva). Indeed, in both cases the knowledge of external things (which Spinoza treated as a modi of God's attributes, and Solovyov, in turn, as rooted in the absolute) means, ultimately, the knowledge of the divine reality. However, there is an important difference between the two thinkers. All three Spinozian "kinds of knowledge" concern only the degree of adequacy of cognition: "knowledge of the first kind we have $\langle\ldots\rangle$ assigned all those ideas, which are inadequate and confused," while "to the second and third kinds of knowledge those ideas which are adequate; therefore these kinds are necessarily true idea of true and false" [19]. In contrast, the above-presented Solovyovian stages of cognition - especially the second and third - are not only the ways of cognition, but also ways for the ontological transformation of the essences of beings embedded in the absolute. As a result, the cognitive approach of beings in the form of intelligible ideas and empirical phenomena is possible.

Generally speaking, the Eastern Christian religious-mystical tradition is met with an attempt to rational justification of cognition in the style of modern Western philosophy in Solovyov's epistemology. The Russian thinker wants to harmonize the teaching on the direct approach of the trans-empirical, divine reality with the requirements of critical, post-Kantian thought. Every cognitive act means moving into the sphere of all-unity. So- 
lovyov expressed this thought in the following way: "We imagine a choice not between transcendent and immanent kinds of cognition, but between transcendent cognition and the negation of any kind of cognition" [20, p. 103]. In this respect, the outstanding historian of Russian philosophy Vasilii Zenkovsky (1881-1962) described Solovyov's concepts as "transcendental realism" [21, p. 123-124].

\section{The Methodological Aspect}

Solovyov treats faith, reason and experience as correlates of religion, philosophy and science. Taken separately, these elements, which determine the mystical, rational and empirical cognition respectively, are termed "abstract principles," i. e. detached from any connection with others and, as a consequence, lead to extreme forms of fideism, rationalism and empiricism. Therefore, Solovyov put forward the aforementioned postulate of unification of faith, reason and experience (theology, philosophy and science) in the system of integral knowledge.

What is more, the various factors or stages of cognition can also be considered as representatives of various fields of knowledge. Namely, "faith" which informs about the independent existence of the object, plays a special role in theology, attesting to the presence of the divine sphere. "Intellectual intuition" or "imagination", explaining "what a subject is", is a privileged means of philosophy, while "creativity", which enables access to reality through a phenomenon, finds its application in positive science. According to Solovyov, in extreme cases (such as positivism, rationalism and fideism) the aforementioned principles obtain an "abstract" character which results in the abandonment of objective knowledge. Neither positive science, based on the perception of phenomena, nor Hegelian rationalistic philosophy, nor traditional Orthodox theology, based purely on faith in God, can capture all aspects of the real metaphysical principle, i. e. all-unity. Since the very process of cognition is a synthesis of faith, intellectual intuition and creativity, its terminus ad quaem, i.e. knowledge itself, should be a synthesis of theology, philosophy and science - the fields in which the above-mentioned ways of cognition are reflected.

In order to build a system of integral knowledge, or free theosophy, there is no need to add any new element, it is sufficient to carry out a structural reorganization of existing fields of knowledge. As George Florovsky (1893-1979) remarked, "the falsehood of any judgment, confirmation or evaluation was seen not in its positive content, not in its nature (physis), but in its nonobligatory position (thesis) in the system of knowledge, i.e. in the incompleteness or one-sidedness" [22, p. 110]. According to Vyacheslav Moiseev, integral knowledge has a holomorphic character: "the parts of the whole potentially contain the whole itself and this whole can be recreated from them" [23, p. 54]. In other words, potentially, philosophy, theology and science can be considered - pars pro toto - as integral knowledge or free theosophy.

Solovyov most probably borrowed the term "theosophy" from Jakob Boehme, although he gave it his own meaning. The Russian thinker wanted to stress that the goal of the new system of knowledge relies on knowing God (hence, "theosophy" - "divine wisdom"), while retaining, at the same time, the relative independence of the "secular" fields of knowledge (hence, "free theosophy"). Let us consider the second name for the Solovyovian program - "integral knowledge". It is not difficult to notice that Solovyov refers to 
the works of the Slavophiles, especially those of Ivan Kireevsky, who proclaimed "integral knowledge" to be based on the "new principles of philosophy" [24]. Solovyov's thinking also reflects the so-called academic philosophy: the concepts of the above-mentioned Pamfil Yurkevich, and the "patriarch of Russian theism" Fedor Golubinsky (1797-1854), who thought about two aims of cognition: love of human wisdom ("philosophy") and divine Wisdom ("theosophy") [25, p.49].

On the one hand, Solovyov writes about the equality of all components of the integral philosophy (resp. free theosophy) - the mystical, rational and empirical element. On the other hand, he clearly stresses that the leading position belongs to theology which captures "the absolute existence and the absolute essence of things" [11, p. 308]. Solovyov was convinced that "mysticism plays a role of supreme importance in this synthesis, and therefore he was especially anxious to delineate the distinguishing features of mystical apprehension" [26, p. 100], or faith. But mystical cognition itself is one-sided in nature. Therefore, theology should be wrapped in a form of rational thinking and maintain close contact with empirical data, which allows traditional theism to be replaced with "free theosophy". It is worth noting that such a tendency to create all-embracing systems, also in the sphere of epistemology, is a characteristic feature not only of Solovyov's work, but Russian religious philosophy in general.

\section{Conclusion}

Let us quote Solovyov's words which come from his entry "Faith (Philosophical)" written for the famous Russian edition of The Brockhaus and Efron Encyclopedic Dictionary: "The foundations of faith lie deeper than knowledge and thinking, hence it is a primordial fact in relation to them. $\langle\ldots\rangle$ [Faith] is a more or less direct or indirect, simple or complex, manifestation of the pre-reflective relationship between the subject and the object in consciousness" [27, p. 553].

Hence, faith reveals the existential dimension of beings. By emphasizing this, Solovyov provides an expression of so-called ontologism, i. e., "the primacy of the concept of being over that of consciousness or knowledge" which "may be considered as a typically national trait of Russian philosophical thought" [28, p. 7, 10]. "Faith", understood as an approach to the existential aspect of the object, opens the way to its further description in rational and empirical categories and thus constitutes a conditio sine qua non of any cognition. Faith is an antidote to all manifestations of skepticism, which undermines the possibility of achieving true knowledge, as well as the deficiencies of "abstract" directions of empiricism and rationalism, neglecting the cognitive understanding of the objective principle of existence.

Opponents of Solovyov, such as Boris Chiczerin (1828-1904) in his work Mysticism in Science, accused him of the fact that in order to state the real existence of things it is not necessary to refer to the religious principle, i. e. faith, since ordinary external experience is enough [29, p. 141-142]. The question arises: why does Solovyov introduce the element of faith into his theory of cognition? Before we answer it, let us note that treating faith as a certainty about the real existence of a thing, which enables its further cognition, was not only criticized by Solovyov's contemporaries. It also received a lively approval from other Russian thinkers. It is worth looking at their proposals, which shed some light on the views of Solovyov himself. For instance, Sergei Trubetskoy 
(1862-1905) almost literally repeated Solovyovian thought in his work The Foundations of Idealism (1896):

Faith as an inevitable element of our sensual and rational cognition $\langle\ldots\rangle$ convinces us of the reality of the external world, the reality of the objects of the senses and reason $<\ldots>$ Thus, there is no impassable gap between religious faith and that faith, which is the fundamental principle of our cognition, because the object of one and the other has a common term - "being", <...> Although the tasks and ways of cognition in religion and philosophy are different, there is no contradiction between them [30, p. 581].

As we can see, "faith" has a very broad meaning for Trubetskoy and Solovyov. It expresses certainty about the existence of any object of cognition - both empirical things and God. In short, Russian thinkers tried to make an analogy between "faith" in an epistemic aspect and religious faith. After all, Solovyov insists that his programme of rebuilding metaphysics (from the position of ontological and epistemological realism) was entirely subordinated to his aspirations to express religious truths in philosophical terms. The emphasis on the existential aspect of being was dictated not only by this philosophical (epistemological and ontological) goal, but also by the project of applying philosophy to the theological discourse. It is here that Solovyov follows in the footsteps of Schelling, who in his "positive philosophy" (contrary to the purely rational "negative" philosophy from the first period) stemmed from the experience of God. In such an approach, the terminus a quo of philosophy is not a formal rational principle, detached from the actual reality, but an existential moment, expressed by "faith" in the broadest meaning of the word [31, p.286]. "Faith" allows divine reality to be captured and which, in Solovyov's opinion, also includes an empirical sphere. As a special cognitive disposition, faith precedes rational reflection. It is the initial stage not only of knowledge of God, but also of knowledge of the world. Consequently, "The existence of God, like all existence in general, may only be given through a 'leap of faith', an immanent vision, and this leap of faith must be the starting point for all philosophy. It is only religious experience, mystical intuition, which can justify the objective reality of the idea of the Absolute. But its role does not cease there. It is also this intuition, and it alone that reveals the positive content of this idea" [32, p. 20].

In his Lectures on Divine Humanity Solovyov claims: "The complete and absolute certainty of its (God's and any object's at all. - T. O.) existence can be given only by faith. $<\ldots>$ That reality is, we believe, but what it is, we experience and know" [10, p.30-31].

At the same time, faith is not self-sufficient, because determining the positive content of being also requires the participation of rational and empirical elements. Solovyov explains that faith, reason and experience do not contradict each other, but are complementary factors of the cognitive process and, more broadly, of all kinds of knowledge as such.

In this case, there should be no conflict between faith and reason which is a step further in the cognitive process. Thanks to faith, the primary cognitive approach to God (which has a special significance for theology) as well as the presentation of things as existing (which, in turn, is a starting point of philosophical and scientific undertaking, not to mention colloquial cognition) is possible. Faith understood in this way is a "praphenomenon of both religion and science" [33, p. 15]. The following statement by Solovyov illustrates this idea: "It is doubtful that a thinker negating the reality of the external world would devote himself to physics" [34, p. 297]. Of course, the thesis on the real existence of 
the world is of a strictly metaphysical character: "physics does not discuss the problem of existence; it simply presupposes that the subject-matter of its investigation does exist" [35, p. 10]. Solovyov was aware that

No astronomy could prove to us the sun's existence and not require any confirmation of its certainty from astronomical theories. The task of science as regards this object consists only in giving us new, clearer, more precise, and more complete concepts of that combination of phenomena which we call the sun. The question of whether some reality that exists outside our consciousness corresponds to these phenomena and concepts, this question of the existence of the object is in no way posed or resolved by science, which is concerned only with the relationship among phenomena $[1, \mathrm{p} .40]$.

At the same time, Solovyov highlights the fact that scientists accept the real, objective existence of objects examined by them exclusively through faith. This position expresses a strong ontological realism confessed by Solovyov, the epistemological expression of which is to be faith. Its task is to show the objective foundation of reality. What is more, "affirming an epistemological fideism, Solov'èv asserted that the start of the true scientific endeavor is a faith in science" [36, p. 108].

Faith as a condition (or stage) of cognition is a kind of bridge that connects all kinds of knowledge and expresses the links between them. It is not by chance that the "integral knowledge" postulated by Solovyov is to be based on the positive religious principles - a "mystical cognition," also known as faith. For Solovyov, "the relationship between faith and reason was, in a way, a condition of his philosophy, because, on the one hand, he sought to create a philosophical system which would be favorable for the understanding of faith, in accordance with the expectations of contemporary consciousness, and, on the other hand, one which would prove, with the help of this philosophical system, that the highest demands of the heart and reason are fulfilled precisely by the Christian religion" [37, p. 80].

Many scholars noticed that the concept of integral knowledge proposed by Solovyov has many shortcomings. For instance, Lev Lopatin (1855-1920) observed that Solovyov

held that the philosopher $\langle\ldots\rangle$ will obtain real knowledge only when he has, living in his spirit, this power of higher contemplation of what is truly real in himself. This realistic faith in a spiritual world, explains the vitality, integrity and concrete character of Solovyov's system. The same faith, however, may be held responsible for its chief defect. $<\ldots>$ Solovyov failed to differentiate between statements actually possessing the necessary logical certainty and statements that were merely probable or even possible or conceivable only. In this characteristic defect of Solovyov's philosophy one can see the peculiarity of a poet's mind: since for a poet the general idea of his work, and all the details and particulars of its realisation are both equally dear [38, p. 436].

At the same time, as Vasilii Zenkovsky rightly noticed, the very idea of synthesis of religion, philosophy and science had a powerful influence on the later development of the original Russian thought [39, p.245]. Solovyov "did not believe that 'faith' and 'reason' were intrinsically incompatible, nor could he agree with Auguste Comte that 'religion' had been superseded by 'methaphysics' in the course of the intellectual evolution of mankind. $\langle\ldots\rangle$ There is no sharp division between 'religious' and 'secular' knowledge. Knowledge is inescapably 'religious' because it fulfills its function only if it succeeds in relating every particular or partial information to the absolute center of reality" [31, p. 283-284, 286]. 
The Solovyovian postulate of the "universal synthesis of science, philosophy, and religion" was supposed to affirm the "ultimate necessary result of the Western philosophical development" in "the form of rational knowledge, the same truths that have been affirmed in the form of faith and spiritual contemplation" [40, p.49]. Nevertheless, it was faith that determines every process of cognition and integral knowledge as a whole.

\section{References}

1. Solovyov, V. (1999), The Concept of God, transl. by Jakim, B., in The Concept of God: Essays on Spinoza, Carlisle: Variable Press, pp. 25-50.

2. Lozev, K.D. (2017), Solovyov's Philosophy as Rationalization of Religious Feelings and Behaviour, Revista de Antropología y Filosofia de lo Sagrado, no. 2, pp. 45-59.

3. Solovyov, V. (2014), Selected Letters to Ekaterina Romanova, in Solovyov, V., Sophia, God and A Short Tale about the Antichrist, transl. by Jakim, B., Ketterin: Angelico Press - Semantron Press, pp. 71-100.

4. Solovyov, V. (2019), God is all. All becomes God, Solovevskie issledovaniia, no. 62, pp. 19-38. (In Russian)

5. Solovyov, V. (1877), Faith, reason and experience, Grazhdanin, no. 41-44, pp. 886-888. (In Russian)

6. Solovyov, V. (1994), Faith, reason and experience, Voprosy filosofii, no. 1, pp. 111-128. (In Russian)

7. Nosov, A. A. (2001), Comments, in Solovyov, V. S., Complete works and letters, in 20 vols., vol. 3, Moscow: Nauka Publ., pp. 514-516. (In Russian)

8. Frank, S. (1909), William James and religious experience. Emile Boutroux. Science et religion dans la philosophie contemporaine, Kriticheskoe obozrenie, vol. VI, pp. 386-387. (In Russian)

9. Brooke, J.H. (2014), Science and Religion. Some Historical Perspectives, Cambridge: Cambridge University Press.

10. Solovyov, V. (1995), Lectures on Divine Humanity, transl. by Jakim, B., Hudson: Lindisfarne Press.

11. Solovyov, V.S. (2001), Critique of abstract principles, in Solovyov, V.S., Complete works and letters, in 20 vols., vol. 3, Moscow: Nauka Publ., pp. 7-360. (In Russian)

12. Obolevitch, T. (2019), Faith and Science in Russian Religious Thought, Oxford: Oxford University Press.

13. Mochul'skiy, K. V. (1995), Vladimir Soloviev. Life and teaching, in Mochul'skiy, K. V., Gogol', Solov'ev, Dostoevskiy, Moscow: Respublika Publ., pp. 63-216. (In Russian)

14. Solov'ev, V. (2019), On the Philosophical Works of P. D. Iurkevych, transl. by Hantula, R., East/West: Journal of Ukrainian Studies, vol. VI, no. 2, pp. 177-197.

15. Walicki, A. (1989), The Slavophile Controversy. History of a Conservative Utopia in NineteenthCentury Russian Thought, transl. by Andrews-Rusiecka, H., Notre Dame: University of Notre Dame Press.

16. Ern, V. (1994), Gnoseology of V.S. Soloviev, in Collection of articles about V. Solovyov, Bruxelles: Zhizn's Bogom Publ., pp. 167-257. (In Russian)

17. Dobieszewski, J. (2002), Włodzimierz Sołowjow. Studium osobowości filozoficznej, Warsaw: Scholar.

18. Shein, L. J. (1977), V. S. Solovyov's Principle of Integral Knowledge, Indian Philosophical Quarterly, no. 4 , pp. 527-539.

19. Spinoza, Ethics. Available at: https://en.wikisource.org/wiki/Ethics (Spinoza)/Part_2 (accessed: 27.12.2019).

20. Solovyov, V. (2008), The Philosophical Principles of Integral Knowledge, transl. by Nollan, V.Z., Cambridge, Michigan: William B. Eerdmans Publishing Company.

21. Zen'kovskiy, V. V. (1997), Foundation of Christian philosophy, vol. 1, Moscow: Kanon + Publ. (In Russian)

22. Florovsky, G. (1989), Human Wisdom and the Great Wisdom of God, in Florovsky, G., Collected Works, vol. 12, Belmont: Nordland Publishing Company, pp. 110-121.

23. Moiseev, V. I. (2002), Logic of all-unity, Moscow: Per Se Publ. (In Russian)

24. Kireevsky I. (1998), On the Necessity and Possibility of New Principles in Philosophy, in On Spiritual Unity. A Slavophile Reader, transl. by Jakim, B. and Bird, R., Hudson: Lindisfarne Books, pp. 233-273.

25. Akulinin, V.N. (1990), Philosophy of all-unity: from V.S. Soloviev to P.A. Florensky, Novosibirsk: Nauka Publ. (In Russian)

26. Sutton, J. (1988), The Religious Philosophy of Vladimir Solovyov. Towards a Reassessment, New York: St. Martin's Press.

27. Solovyov, V.S. (1970), Faith (philos.), in Collected works of Vladimir Sergeevich Solovev, vol. XII, Bruxelles: Zhizn's Bogom Publ., p. 553. (In Russian) 
28. Frank, S. (1927), Contemporary Russian Philosophy, The Monist, vol. 37, no. 1, pp. 1-23.

29. Chicherin, B. N. (1880), Mysticisim in philosophy, Moscow: Tipografiia Martynova Publ. (In Russian)

30. Trubetskoy, S. (2000), Foundation of idealism, in Trubetskoy, S., The Teaching on Logos in its history, Moscow: Izd. AST Publ., Kharkiv: Folio Publ., pp. 498-637. (In Russian)

31. Florovsky, G. (1955), Reason and Faith in the Philosophy of Solov'ev, in Simmos, E. J. (ed.), Continuity and Change in Russian and Soviet Thought, Cambridge, Michigan: Harvard University Press, pp. 283-297.

32. Kojève, A. (2018), The Religious Metaphysics of Vladimir Solovyov, transl. by Merlin, I. and Pozdniakov, M., London: Palgrave Macmillan.

33. Nekrasova, E. N. (1997), Living truth. Metaphysics of human being in Russian religious philosophy of the $20^{\text {th }}$ century, Moscow: Martis Publ. (In Russian)

34. Solovyov, V.S. (1966), On the way to true philosophy, in Collected works of Vladimir Sergeevich Solov'ev, vol. III, Bruxelles: Zhizn's Bogom Publ., pp. 255-269. (In Russian)

35. Heller, M. (2018), What Does it Mean “To Exist” in Physics?, Zagadnienia Filozoficzne w Nauce, vol. 65 , pp. $9-22$.

36. Nemeth, Th. (2019), The Later Solovềv. Philosophy in Imperial Russia, Cham: Springer.

37. Dianin-Khavard, A. (2004), Vladimir Soloviev: faith, reason and heart, in Porus, V. (ed.), Russia and the Universal Church: V.S. Solovyov and the problem of religious and cultural unity of mankind, Moscow: BBI Publ., pp. 80-95. (In Russian)

38. Lopatin, L. M. (1916), The Philosophy of Vladimir Soloviev, Mind, vol. 25, no 100, pp. 436.

39. Zen'kovskiy, V. V. (2008), The idea of all-unity in the philosophy of Vladimir Soloviev, in Zen'kovskiy, V. V., Collected works, vol. 1, Moscow: Russkii put' Publ., pp. 425-460. (In Russian)

40. Solovyov, V. (1996), The Crisis of Western Philosophy (Against the Positivists), transl. by Jakim, B., Hudson: Lindisfarne Press.

Received: January 11, 2020

Accepted: July 2, 2020

Author's information:

Teresa Obolevitch — Dr. Sci. in Philosophy, Professor; tereza.obolevich@upjp2.edu.pl

\section{Значение веры в концепции цельного знания Владимира Соловьева}

\section{Т. Оболевич}

Папский университет Иоанна Павла II в Кракове,

Республика Польша, 31-002, Краков, ул. Канонича, 9

Национальный исследовательский университет «Высшая школа экономики»,

Российская Федерация, 101000, Москва, ул. Мясницкая, 20

Для цитирования: Obolevitch $T$. The significance of faith in the concept of integral knowledge of Vladimir Solovyov // Вестник Санкт-Петербургского университета. Философия и конфликтология. 2020. Т. 36. Вып. 3. С. 460-472. https://doi.org/10.21638/spbu17.2020.304

В статье рассматриваются роль и место веры в концепции создателя первой русской философской системы В.С. Соловьева. Цель исследования состоит в том, чтобы определить эпистемологическое и методологическое значение веры в понимании Соловьева как особого фактора познания. Для этого использованы синтетический метод, позволяющий реконструировать мысль Соловьева, а также метод философского анализа. Вначале представлен соловьевский проект цельного знания, или вольной теософии, т. е. синтеза философии, богословия и науки. Раскрыты предпосылки этой концепции и указан ее полемический контекст, а именно попытка преодоления отвле-

* Статья подготовлена в ходе проведения работы в рамках Программы фундаментальных исследований Национального исследовательского университета «Высшая школа экономики» (НИУ ВШЭ) и с использованием средств субсидии в рамках государственной поддержки ведущих университетов Российской Федерации «5-100». 
ченных, т.е. односторонних, начал: разума, эмпирического опыта и веры - с целью создания системы, объединяющей все виды знания. При этом разуму как таковому соответствует философия, опыту - наука, а вере - богословие. Вторая часть статьи посвящена эпистемологическому аспекту веры в теории цельного знания. Он заключается в том, что каждый акт познания начинается с утверждения существования его предмета, которое Соловьев называет верой в широком смысле этого слова. Таким образом, вера приобретает универсальное значение как необходимое условие познавательного процесса. В третьей части рассматривается методологический аспект веры как ключевого звена в системе цельного знания. Из этого следует, что вере принадлежит главенствующая роль не только в богословии, но во всех областях знания, в том числе философии и науке. Таким образом, можно сделать вывод, что между верой и разумом нет конфликта, напротив, они взаимодополняют друг друга. Позиция Соловьева актуальна и в наши дни.

Ключевые слова: вера, цельное знание, теософия, опыт, наука.

Статья поступила в редакцию 11 января 2020 г;; рекомендована в печать 2 июля 2020 г.

Контактная информация:

Оболевич Тереза - д-р филос. наук, проф.; tereza.obolevich@upjp2.edu.pl 